\title{
Simulasi Pola Tanam Pada Sembilan Daerah Irigasi Tersebar di Kota Kupang
}

\author{
Simulation of Planting Patterns in Nine Irrigation Areas in Kupang City
}

\author{
Ayu P.Paramitha ${ }^{1}$, Rosmiyati A. Bella ${ }^{1}$, Dolly W. Karels ${ }^{1}$, Denik S. Krisnayanti ${ }^{1 *}$ \\ ${ }^{1}$ Program Studi Teknik Sipil, Fakultas Sains dan Teknik, Universitas Nusa Cendana, Kupang, Indonesia
}

\begin{abstract}
Article info:
Abstrak

Kata kunci:

Fatukoa, neraca air, simulasi pola tanam

Kota Kupang dengan luas $180.27 \mathrm{~km}^{2}$, memiliki dua musim yaitu musim kemarau dan musim hujan. Kota Kupang memiliki sembilan daerah irigasi yang terletak tersebar di Kota Kupang. Pada musim kemarau sering timbul kekeringan pada areal pertanian yang Keywords:

Fatukoa, planting pattern simulation, water balance mengakibatkan gagal panen. Penelitian ini bertujuan untuk mengetahui pola tanam pada daerah irigasi di Kota Kupang yang optimal sesuai dengan keseimbangan air yang terjadi antara debit andalan dan kebutuhan air irigasi. Metode untuk menghitung evapotranspirasi digunakan metode Penman Modifikasi dan analisis debit andalan menggunakan metode F.J. Mock. Berdasarkan hasil

Article history:

Received: 23-05-2020

Accepted: 28-11-2020 penelitian, besar kebutuhan air irigasi yang terbesar adalah pada Daerah Irigasi Fatukoa untuk pola tanam padi-palawija-palawija sebesar $0.00-0.25 \mathrm{~m}^{3} / \mathrm{dtk}$ dan padi-padi-palawija sebesar $0.01-0.47$

${ }^{*}$ Koresponden email: denik.krisnayanti@staf.undana.ac.id $\mathrm{m}^{3} / \mathrm{dtk}$. Untuk neraca air Daerah Irigasi Fatukoa dengan pola tanam padi-palawija-palawija tahun normal $\left(\mathrm{Q}_{50}\right)$ sebesar $-0.25-2.39 \mathrm{~m}^{3} / \mathrm{dtk}$ dan tahun kering $\left(\mathrm{Q}_{80}\right)$ sebesar $-0.25-1.46 \mathrm{~m}^{3} / \mathrm{dtk}$. Untuk sembilan daerah irigasi di Kota Kupang, pola tanam yang sesuai untuk tahun normal $\left(\mathrm{Q}_{50}\right)$ adalah padi-palawija-palawija dan untuk tahun kering $\left(\mathrm{Q}_{80}\right)$ adalah padi-palawija-palawija.
\end{abstract}

\begin{abstract}
Kupang city with an area of $180.27 \mathrm{~km}^{2}$ has two seasons that are a dry season and a rainy season. Kupang City has nine Irrigation Areas that spread in Kupang City. In the dry season, the drought always occurs in the irrigation area that causes crop failures. This research has the purpose to find out the optimal crop pattern in Kupang City irrigation areas that corresponds to the occurrence of water balance between main discharge and irrigation water requirements. The method for calculating evapotranspiration used the Penman modification method and dependable discharge analysis using the F.J. Mock. Based on the results, the largest irrigation water requirements of this research are in Fatukoa's irrigation area with the planting pattern is paddy-secondary crops-secondary crops is $0.00-0.25 \mathrm{~m}^{3} / \mathrm{sec}$ and for the crop pattern paddy-paddy-secondary crops are $0.01-0.47 \mathrm{~m}^{3} / \mathrm{sec}$. The Fatukoa's water balance for the planting pattern, paddy-secondary cropssecondary crops is $-0.25-2.39 \mathrm{~m}^{3} / \mathrm{sec}$ and $-0.25-1.46 \mathrm{~m}^{3} / \mathrm{sec}$ with the main discharge in a normal year $\left(\mathrm{Q}_{50}\right)$ and dry year $\left(\mathrm{Q}_{80}\right)$. In the nine irrigation areas in Kupang City the suitable planting pattern for the normal year $\left(\mathrm{Q}_{50}\right)$ is paddy-secondary crops and for the dry year $\left(\mathrm{Q}_{80}\right)$ is paddy-secondary crops.
\end{abstract}

Kutipan: Paramita, A.P., Bella, R.A., Karels, D.W., \& Krisnayanti, D.S. (2020). Simulasi Pola Tanam Pada Sembilan Daerah Irigasi Tersebar di Kota Kupang. Jurnal Teknik Pengairan. https://doi.org/10.21776/ub.pengairan.2020.011.02.04 


\section{Pendahuluan}

Kota Kupang merupakan ibu kota dari Provinsi Nusa Tenggara Timur yang memiliki luas wilayah $180.27 \mathrm{Km}^{2}$ (Kantor Pertanahan Kota Kupang) dan terdiri dari enam Kecamatan dan 51 Kelurahan dengan jumlah penduduk berdasarkan Rencana Tata Ruang Wilayah (RTRW) pada tahun 2018 adalah 412,708 jiwa (Badan Pusat Statistik 2018). Kota Kupang secara umum memiliki musim kemarau yang lebih panjang daripada musim hujan dalam satu tahun, hal ini ditandai dengan iklim kering sedang (semi-arid) di Kota Kupang berdasarkan data Rencana Pembangunan Jangka Menengah Daerah (RPJMD) tahun 2011-2016 (Badan Pusat Statistik 2017). Pada musim kemarau sering timbul kekeringan pada areal pertanian yang mengakibatkan gagal panen. Kekeringan tersebut timbul karena ketersediaan sumber daya air berbanding terbalik dengan kebutuhan dan pemanfaatannya.

Selain kekeringan pada areal pertanian yang ada di Kota Kupang, muncul masalah lain akibat pertambahan penduduk. Pertambahan penduduk yang meningkat, dapat menyebabkan berbagai dampak bagi lingkungan. Salah satunya adalah alih fungsi lahan pertanian ke lahan nonpertanian. Di beberapa daerah di wilayah Kota Kupang, areal pertanian semakin berkurang karena telah dikonversi menjadi kawasan pemukiman, perdagangan dan industri. Di Kota Kupang sendiri, terdapat sembilan Daerah Irigasi (DI) yang dalam pemanfaatannya, masih kurang optimal oleh masyarakat yang berada di sekitar daerah irigasi tersebut. Adapun beberapa daerah irigasi tersebut adalah Daerah Irigasi Amnesi (36 ha), Daerah Irigasi Batuplat (90 ha), Daerah Irigasi Belo (60 ha), Daerah Irigasi Fatukoa (114 ha), Daerah Irigasi Oelon Haukolo (50 ha), Daerah Irigasi Labat (20 ha), Daerah Irigasi Oepura (65 ha), Daerah Irigasi Lasiana (8 ha), dan Daerah Irigasi Kolhua (45 ha).

Dalam hal pemanfaatan sumber daya air, sampai saat ini belum optimal salah satunya dikarenakan belum diketahuinya pola tanam yang paling efisien ditinjau dari pemanfaatan debit air dan kebutuhan air irigasi di sembilan daerah irigasi tersebut. Oleh karena itu, perlu adanya penelitian mengenai pemanfaatan sumber daya air di sembilan daerah irigasi Kota Kupang yang berada pada daerah semi-arid dengan cara mengoptimalkan pola tanam yang efisien.

Beberapa penelitian yang telah dilakukan sebelumnya di daerah semi-arid di Nusa Tenggara Timur, seperti simulasi pola tata tanam di Daerah Irigasi Raknamo (Krisnayanti et al. 2020), daerah irigasi di Kabupaten Sumba Tengah (Banjarnahor and D. Simanjuntak 2015), DI Weliman di Kabupaten Malaka (Sayonara and Siswoyo 2019), DI Siafu di Kabupaten Timor Tengah Selatan (Bunganaen et al. 2020), dan Kecamatan Lewa di Sumba Timur (Killa et al. 2019). Penelitian terdahulu juga menunjukkan bahwa optimalisasi pola tanam di daerah semi kering ini idealnya hanya 1 - 2 kali masa tanam dalam satu tahun. Hal ini dikarenakan rendahnya curah hujan tahunan yang berkisar $800 \mathrm{~mm}-1,200 \mathrm{~mm} /$ tahun.

Berdasarkan hal tersebut diatas, maka tujuan dari penelitian ini adalah untuk mengetahui pola tanam yang paling optimal sesuai dengan neraca air/keseimbangan air yang ada pada sembilan Daerah Irigasi di Kota Kupang.

Tabel 1. Lokasi Daerah Irigasi di Kota Kupang

\begin{tabular}{clccc}
\hline NO. & Nama Daerah Irigasi & Kecamatan & Lintang Selatan & Bujur Timur \\
\hline 1 & D.I. Amnesi & Oebobo & $10^{\circ} 11^{\prime} 41.3^{\prime \prime} \mathrm{S}$ & $123^{\circ} 35^{\prime} 31.9^{\prime \prime} \mathrm{E}$ \\
2 & D.I. Batuplat & Alak & $10^{\circ} 11^{\prime} 54.8^{\prime \prime} \mathrm{S}$ & $123^{\circ} 34^{\prime} 56.3^{\prime \prime} \mathrm{E}$ \\
3 & D.I. Belo & Maulafa & $10^{\circ} 13^{\prime} 03.6^{\prime \prime} \mathrm{S}$ & $123^{\circ} 35^{\prime} 00.6^{\prime \prime} \mathrm{E}$ \\
4 & D.I. Fatukoa & Maulafa & $10^{\circ} 12^{\prime} 50.7^{\prime \prime} \mathrm{S}$ & $123^{\circ} 36^{\prime} 05.9^{\prime \prime} \mathrm{E}$ \\
5 & D.I. Kolhua & Maulafa & $10^{\circ} 12^{\prime} 39^{\prime \prime} \mathrm{S}$ & $123^{\circ} 38^{\prime} 114^{\prime \prime} \mathrm{E}$ \\
6 & D.I. Labat & Oebobo & $10^{\circ} 11^{\prime} 426^{\prime \prime} \mathrm{S}$ & $123^{\circ} 35^{\prime} 43.6^{\prime \prime} \mathrm{E}$ \\
7 & D.I. Lasiana & Kelapa Lima & $10^{\circ} 07^{\prime} 58.9^{\prime \prime S}$ & $123^{\circ} 40^{\prime} 32 .^{\prime \prime} \mathrm{E}$ \\
8 & D.I. Oelon-Haukolo & Maulafa & $10^{\circ} 12^{\prime} 11.3^{\prime \prime} \mathrm{S}$ & $123^{\circ} 36^{\prime} 54.9^{\prime \prime} \mathrm{E}$ \\
9 & D.I. Oepura & Maulafa & $10^{\circ} 11^{\prime} 27.8^{\prime \prime S}$ & $123^{\circ} 36^{\prime} 43.8^{\prime \prime} \mathrm{E}$ \\
\hline
\end{tabular}




\section{Bahan dan Metode}

\subsection{Lokasi Studi}

Penelitian ini dilakukan di daerah irigasi di Kota Kupang yang terletak pada 10'36'14" -

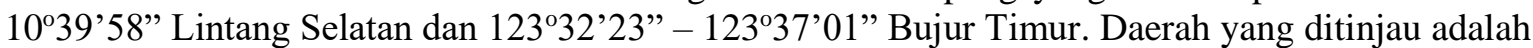
sembilan Daerah Irigasi yakni Daerah Irigasi Amnesi, Daerah Irigasi Batuplat, Daerah Irigasi Bello, Daerah Irigasi Fatukoa, Daerah Irigasi Oelon Haukolo, Daerah Irigasi Labat, Daerah Irigasi Oepura, Daerah Irigasi Lasiana, dan Daerah Irigasi Kolhua, seperti yang ditunjukkan pada Tabel 1 dan Gambar 1.

Secara umum wilayah Kota Kupang termasuk dalam dataran rendah. Topografi wilayah Kota Kupang berada pada ketinggian antara $0-350$ mdpl. Wilayah tertinggi di Kota Kupang terletak di bagian selatan dengan ketinggian antara 100 - 350 mdpl. Wilayah terendah di Kota Kupang terletak di bagian pesisir utara dan bagian barat.

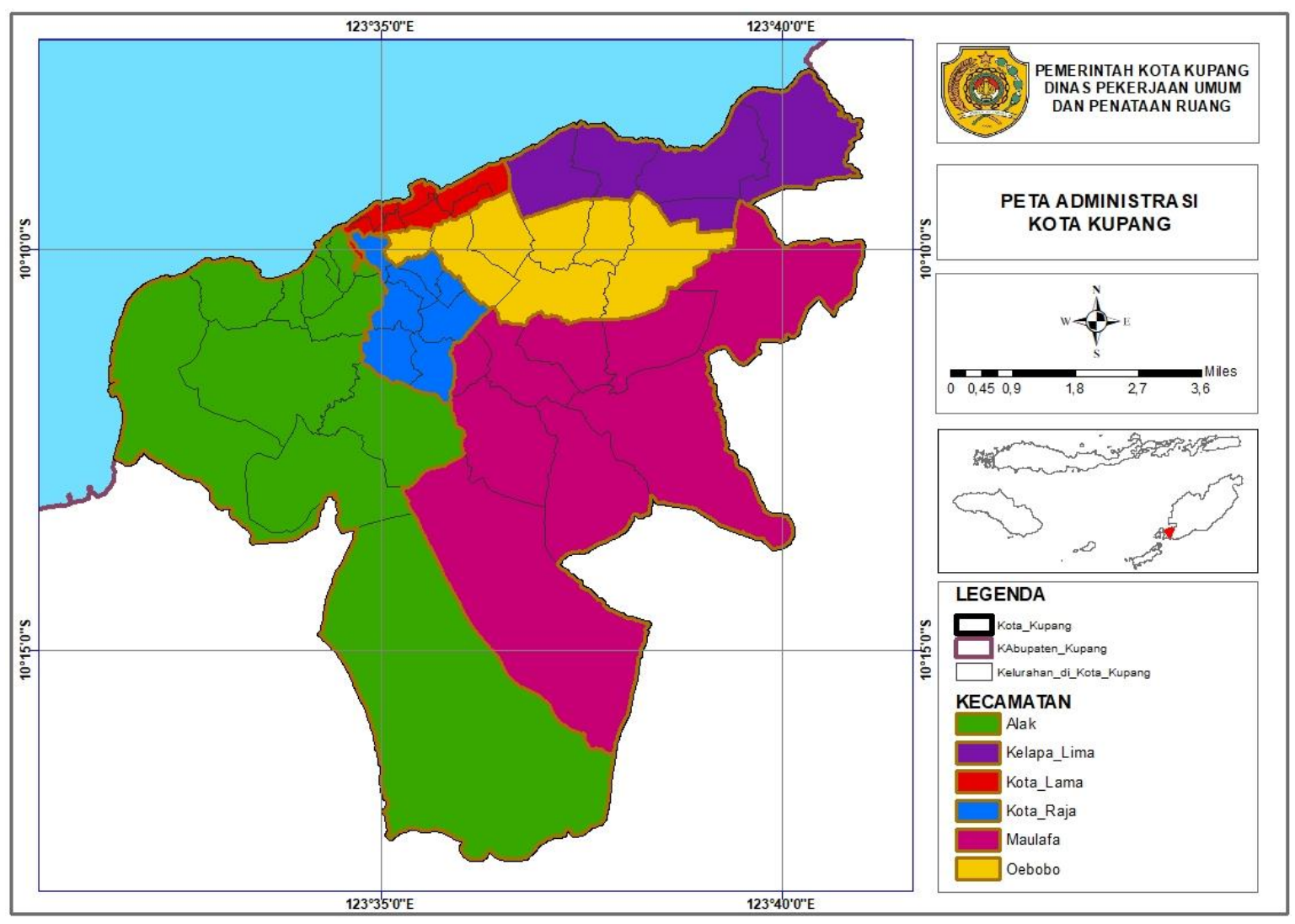

Gambar 1. Lokasi penelitian Daerah Irigasi di Kota Kupang

Sumber: (Dinas Pekerjaan Umum dan Perumahan Rakyat Kota Kupang 2018)

\subsection{Data}

Data yang digunakan dalam studi ini antara lain adalah:

a. Data curah hujan selama 15 tahun dari tahun 2002-2016 yang diambil dari Badan Meteorologi, Klimatologi dan Geofisika Lasiana di Kota Kupang (Badan Meteorologi Klimatologi dan Geofisika (BMKG) 2019)

b. Data klimatologi selama 15 tahun dari tahun 2002-2016 yang diambil dari Badan Meteorologi, Klimatologi dan Geofisika Lasiana di Kota Kupang dan digunakan untuk menghitung besarnya evapotranspirasi yang terjadi. Data-data klimatologi tersebut terdiri atas lamanya penyinaran matahari, suhu relatif, kelembaban relatif, dan kecepatan angin (Badan Meteorologi Klimatologi dan Geofisika (BMKG) 2019) 
c. Data tentang luas areal potensial diambil dari (Balai Wilayah Sungai Nusa Tenggara II) Satuan Kerja Non Vertikal Tertentu PJPA Sumber Daya Air Balai Wilayah Sungai Nusa Tenggara II.

d. Data-data yang diambil dari literatur-literatur yang berhubungan dengan penelitian ini.

\subsection{Metode Analisis}

Dalam studi ini dilakukan simulasi kebutuhan air irigasi yang optimal sesuai dengan ketersediaan air yang ada (debit andalan) dengan memperhatikan neraca air (water balance) pada daerah irigasi. Tetapi sebelum melakukan simulasi perhitungan berdasarkan neraca air, maka terlebih dahulu dilakukan perhitungan evapotranspirasi potensial menggunakan metode Penman Modifikasi dan perhitungan debit andalan menggunakan Metode F. J. Mock.

\subsection{Definisi Curah Hujan}

Curah hujan atau presipitasi adalah jumlah air hujan yang turun pada daerah tertentu dalam waktu tertentu. Hujan terbentuk dari kumpulan penguapan uap air (awan) yang jika mencapai titik jenuh akan kembali turun ke bumi. Satuan curah hujan yang digunakan adalah dalam satuan milimeter (mm).

\subsection{Curah hujan efektif}

Curah hujan efektif merupakan curah hujan yang langsung tertangkap pada daerah irigasi dan dapat digunakan untuk memenuhi kebutuhan air tanaman. Curah hujan efektif untuk tanaman padi diambil $70 \%$ dari nilai $\mathrm{R}_{80}$ tengah bulanan dan untuk $50 \%$ dari nilai $\mathrm{R}_{80}$ tengah bulanan untuk tanaman palawija.

\subsection{Evapotranspirasi Potensial}

Dalam perhitungan evapotranspirasi potensial yang dilakukan di dalam penelitian ini menggunakan Metode Penman Modifikasi. Persamaan Penman Modifikasi di daerah Indonesia adalah sebagai berikut (Suhardjono 1994):

$$
\text { Eto }=\text { c } \times E \text { To }^{*}
$$

Dengan:

$\mathrm{c}=$ angka koreksi Penman yang besarnya mempertimbangkan perbedaan cuaca

\subsection{Analisa Debit Andalan}

Debit andalan merupakan debit dari suatu sumber air yang diharapkan dapat disadap dengan resiko kegagalan tertentu (Kriteria Perencanaan Bagian Saluran Kp-01 2013). Berikut adalah kriteria debit andalan yang digunakan dalam penelitian ini:

$>$ Debit Andalan Tahun Normal dengan probabilitas keandalan sebesar 50\% $\left(\mathrm{Q}_{50}\right)$

$>$ Debit Andalan Tahun Kering dengan probabilitas keandalan sebesar 80\% (Q80)

Dalam penelitian ini, data debit sungai yang terukur secara langsung di lapangan tidak tersedia sehingga dalam mendapatkan data debit sungai dalam penelitian ini menggunakan Metode F. J. Mock. Parameter yang diperhatikan dalam Metode F. J. Mock adalah sebagai berikut:

1. Curah hujan

Data curah hujan diperlukan dalam perhitungan debit andalan untuk mengetahui berapa banyak air yang jatuh ke dalam tanah untuk kemudian melalui banyak proses yang kemudian akan menjadi aliran air.

2. Evapotranspirasi potensial

3. Evapotranspirasi terbatas (aktual)

Evapotranspirasi terbatas adalah evapotranspirasi yang terjadi pada kondisi air yang tersedia terbatas. Dalam menghitung besar evapotranspirasi terbatas, diperlukan data:
a. Curah hujan bulanan $(\mathrm{P})$
b. Jumlah hari hujan bulanan (n)
c. Singkapan lahan, exposed surface (m \%)

Nilai m diperoleh dari peta tata guna lahan, atau diasumsi: 
$\mathrm{m}=0 \%$ untuk lahan dengan hutan lebat

$\mathrm{m}=10 \%-40 \%$ untuk lahan yang tererosi

$\mathrm{m}=30 \%-50 \%$ untuk lahan pertanian yang diolah

Secara matematis evapotranspirasi terbatas dirumuskan sebagai berikut:

$$
\begin{aligned}
& E=\text { ETo } \times\left(\frac{\mathrm{m}}{20}\right) \times(18-\mathrm{n}) \\
& E T=\text { ETo }-\mathrm{E}
\end{aligned}
$$

Dengan:

$$
\begin{aligned}
& \mathrm{E} \quad=\text { evapotranspirasi aktual }(\mathrm{mm} / \mathrm{hari}) \\
& \mathrm{ETo}=\text { evapotranspirasi potensial }(\mathrm{mm} / \mathrm{hari}) \\
& \mathrm{m}=\text { singkapan lahan, } \text { exposed surface }(\%) \\
& \mathrm{n}
\end{aligned}
$$

4. Keseimbangan Air di Permukaan Tanah

Keseimbangan air di permukaan tanah adalah bagaimana lapisan di permukaan tanah mempertahankan keseimbangan air yang ada yang berasal dari air hujan, yang kemudian setelah mencapai keseimbangan air pada lapisan permukaan maka sisa air yang ada akan diteruskan ke dalam lapisan tanah yang lebih dalam. Beberapa faktor yang mempengaruhi keseimbangan air di permukaan tanah adalah sebagai berikut:

a. Air Hujan $(\Delta \mathrm{S})$

Air hujan yang mencapai permukaan tanah dihitung dengan persamaan:

$$
\Delta S=P-e a
$$

Dengan:

$\Delta \mathrm{S}=$ keseimbangan air di permukaan tanah $(\mathrm{mm})$

$\mathrm{P} \quad=$ curah hujan bulanan $(\mathrm{mm} /$ hari)

ea $=$ evapotranspirasi terbatas $(\mathrm{mm} / \mathrm{hari})$

b. Perubahan kandungan air tanah

Perubahan kandungan air tanah sangat tergantung pada bagaimana kondisi air hujan yang sampai pada permukaan air tanah. Apabila air hujan yang sampai pada permukaan tanah $(\Delta S)$ nilainya negatif maka akan terjadi pengurangan kandungan air tanah sedangkan jika air hujan yang sampai pada permukaan tanah $(\Delta S)$ nilainya positif maka akan terjadi penambahan kandungan air tanah pada lapisan permukaan tanah.

c. Kapasitas kelembaban tanah (Soil Moisture Capacity)

Persamaan yang digunakan untuk besarnya kapasitas kelembaban tanah sebagai berikut:

$$
\operatorname{SMC}(n)=\operatorname{SMC}(n-1)+I S(n)
$$

Dengan:

$\mathrm{SMC}(\mathrm{n})=$ Kelembaban tanah bulan ke $\mathrm{n}(\mathrm{mm} / \mathrm{bulan})$

$\operatorname{SMC}(\mathrm{n}-1)=$ Kelembaban tanah bulan ke $\mathrm{n}-1$

IS $\quad=$ Tampungan awal (initial storage) $(\mathrm{mm})$

d. Kelebihan air (Water Surplus)

Kelebihan air adalah volume air yang akan masuk ke permukaan tanah. Persamaan yang digunakan untuk menghitung besarnya kelebihan air adalah:

$$
W S=\Delta S-S S
$$

Dengan:

WS = Kelebihan air

$\Delta \mathrm{S}=$ Air hujan mencapai permukaan tanah

$\mathrm{SS}=$ Kandungan air tanah 
5. Aliran dan penyimpanan air tanah

Faktor yang mempengaruhi besar aliran dan penyimpanan air tanah adalah besar kelebihan air (water surplus) yang terjadi pada lapisan permukaan tanah. Setelah kelebihan air yang terjadi pada lapisan permukaan mulai masuk ke lapisan tanah yang lebih dalam, maka berikutnya faktor-faktor lain yang diperlukan untuk menentukan besarnya aliran air tanah adalah sebagai berikut :

a. Infiltrasi

Infiltrasi adalah gerakan vertikal air hujan ke dalam tanah melalui permukaan tanah (Hadisusanto 2010). Dalam penelitian ini, persamaan yang digunakan untuk perhitungan infiltrasi adalah:

$$
I=W S x k
$$

Dengan:

$\mathrm{I} \quad=$ infiltrasi $(\mathrm{mm})$

$\mathrm{k} \quad=$ koefisien infiltrasi (diasumsikan 0-1)

WS $=$ Water surplus $(\mathrm{mm})$

Besar koefisien infiltrasi ditentukan berdasarkan kondisi porositas tanah dan kemiringan daerah pengaliran sungai.

b. Faktor resesi aliran tanah $(\mathrm{K})$

Faktor resesi aliran tanah $(\mathrm{K})$ merupakan perbandingan antara air tanah pada bulan ke-n dengan aliran air tanah pada awal bulan tersebut.

c. Initial Storage (IS)

Initial Storage atau tampungan awal merupakan asumsi volume air awal yang terdapat pada penyimpanan air tanah.

d. Penyimpanan air tanah (Ground Water Storage)

Penyimpanan air tanah besarnya tergantung dari kondisi geologi setempat dan waktu. Persamaan yang dipergunakan dalam perhitungan penyimpanan air tanah adalah sebagai berikut:

$$
\begin{gathered}
V n=k x V(n-1)-0.5(1+k) x I \\
\Delta V n=V n-V(n-1)
\end{gathered}
$$

Dengan:

$\mathrm{K} \quad=$ faktor resesi aliran tanah, $\mathrm{k}=\frac{q t}{q o}$

qt = aliran air tanah pada bulan ke $\mathrm{t}$

qo = aliran air tanah pada awal bulan

$\mathrm{Vn}=$ volume air tanah bulan ke-n

$\mathrm{V}(\mathrm{n}-1)=$ volume air tanah bulan sebelumnya

$\Delta \mathrm{Vn}=$ perubahan volume aliran air tanah

6. Aliran sungai

$$
\mathrm{I} \quad=\text { infiltrasi }
$$

Untuk mendapatkan besarnya aliran sungai dapat ditentukan dengan persamaan:

a. Aliran dasar (Base Flow)

$$
B F=i-\Delta V
$$

Dengan:

$\mathrm{BF}=$ aliran dasar/base flow $(\mathrm{mm} / \mathrm{dtk})$

$\mathrm{i} \quad=$ infiltrasi $(\mathrm{mm})$

$\Delta \mathrm{V}=$ perubahan volume aliran air dalam tanah $(\mathrm{mm})$

b. Aliran permukaan (Direct RunOff)

$$
D R O=V w s-i
$$

Dengan:

$\mathrm{DRO}=$ aliran permukaan/direct runoff $(\mathrm{mm} / \mathrm{dtk})$ 
Vws = volume air lebih (water surplus) (mm)

i $\quad=$ infiltrasi

c. Aliran sungai (Run Off)

$$
R O=D R O-B F
$$

Dengan:

$\mathrm{RO}=$ aliran sungai $/$ run off $(\mathrm{mm} / \mathrm{dtk})$

$\mathrm{DRO}=$ aliran permukaan/direct runoff $(\mathrm{mm} / \mathrm{dtk})$

$\mathrm{BF}=$ aliran dasar/base flow $(\mathrm{mm} / \mathrm{dtk})$

d. Debit andalan

Debit andalan $\left(\mathrm{Q}_{\mathrm{n}}\right)$ dapat dihitung dengan persamaan:

$$
Q_{n}=\frac{A x R O}{86400 \times h}
$$

Dengan:

Qn $=$ debit andalan $\left(\mathrm{m}^{3} / \mathrm{dtk}\right)$

A $=$ luas DAS $\left(\mathrm{m}^{2}\right)$

$\mathrm{RO}=\operatorname{run}$ off $(\mathrm{mm} / \mathrm{dtk})$

$\mathrm{h} \quad=$ jumlah hari dalam 1 bulan (n)

\subsection{Kebutuhan air irigasi}

Dalam perhitungan kebutuhan air irigasi, hal yang paling menentukan besar kebutuhan air irigasi adalah jenis tanaman yang ditanam pada areal irigasi tersebut. Faktor-faktor yang menentukan perbedaan kebutuhan air irigasi antara jenis tanaman adalah antara lain evapotranspirasi (ETc), perkolasi (P), dan juga pergantian lapisan air (WLR) (jika dibutuhkan). Jenis tanaman yang umumnya ditanam pada daerah irigasi Kota Kupang adalah jenis tanaman padi dan palawija.

Perhitungan kebutuhan air irigasi didasarkan pada prinsip keseimbangan air (water balance) yang dinyatakan dalam persamaan (Suhardjono 1994):

$$
N F R=E T c+P-\operatorname{Reff}+W L R
$$

dengan:

$\mathrm{NFR}=$ netto field water requirement, kebutuhan bersih air di sawah $(\mathrm{mm} / \mathrm{hari})$

$\mathrm{ETc}=$ evapotranspirasi tanaman $(\mathrm{mm} / \mathrm{hari})$

$\mathrm{P} \quad=$ perkolasi $(\mathrm{mm} / \mathrm{hari})$

$\mathrm{R}_{\mathrm{eff}} \quad=$ curah hujan efektif (mm/hari)

WLR = penggantian lapisan air $(\mathrm{mm} / \mathrm{hari})$

\section{Hasil dan Pembahasan}

\subsection{Evapotranspirasi tetapan}

Evapotranspirasi dihitung dengan menggunakan Metode Penman Modifikasi menggunakan data klimatologi dari Stasiun Lasiana selama 15 tahun dari tahun 2002 - 2016. Hasil perhitungan menunjukkan bahwa besar evapotranspirasi harian rata-rata berkisar antara $5.35-13.16 \mathrm{~mm} / \mathrm{hari}$. Besar evapotranspirasi harian sembilan Daerah Irigasi secara lengkap dapat dilihat pada Tabel 2.

Berdasarkan data rerata evapotranspirasi potensial sembilan daerah irigasi yang ditunjukkan pada Tabel 2, dapat dilihat bahwa evapotranspirasi potensial maksimum adalah sebesar 13.51 $\mathrm{mm} /$ hari yang terjadi pada bulan Oktober di Daerah Irigasi Lasiana dan nilai evapotranspirasi minimum adalah sebesar $5.23 \mathrm{~mm} /$ hari yang terjadi pada bulan Januari di Daerah Irigasi Fatukoa. 
Tabel 2. Evapotranspirasi sembilan Daerah Irigasi di Kota Kupang

\begin{tabular}{|c|c|c|c|c|c|c|c|c|c|c|c|c|c|c|c|c|c|c|c|c|c|c|c|}
\hline \multirow{3}{*}{$\begin{array}{l}\text { Daerah } \\
\text { Irigasi }\end{array}$} & \multicolumn{23}{|c|}{ Evapotranspirasi Potensial Harian (mm/hari) } \\
\hline & \multicolumn{2}{|c|}{ Jan } & \multicolumn{2}{|c|}{ Feb } & \multicolumn{2}{|c|}{ Mar } & \multicolumn{2}{|c|}{ Apr } & \multicolumn{2}{|c|}{ Mei } & \multicolumn{2}{|c|}{ Jun } & \multicolumn{2}{|c|}{ Jul } & \multicolumn{2}{|c|}{ Agust } & \multicolumn{2}{|c|}{ Sep } & \multicolumn{2}{|c|}{ Okt } & \multicolumn{2}{|c|}{ Nov } & Des \\
\hline & $\mathrm{I}$ & II & $\mathrm{I}$ & II & $\mathrm{I}$ & II & $\mathrm{I}$ & II & $\mathrm{I}$ & II & $\mathrm{I}$ & II & $\mathrm{I}$ & II & $\mathrm{I}$ & II & $\mathrm{I}$ & II & $\mathrm{I}$ & II & $\mathrm{I}$ & II & II \\
\hline Am & 4 & 5.34 & 5.58 & 5.58 & 5.73 & 5.73 & 6.44 & 6.44 & 6.77 & 6.77 & 7.70 & 7.70 & 7.90 & 7.90 & 9.17 & 9.17 & 9.71 & 9.71 & 13.28 & 13.28 & 8.04 & 8.04 & 5.795 .79 \\
\hline . & 4 & 5.34 & 5.53 & 5.53 & 5.68 & 5.68 & 6.52 & 6.52 & 6.79 & 6.79 & 7.65 & 7.65 & 7.86 & 67.86 & 9.11 & 9.11 & 9.65 & 9.65 & 13.20 & 13.20 & 7.99 & 7.99 & 5.755 .75 \\
\hline Bello & & 5.25 & 5.40 & 5.40 & 5.55 & 5.55 & 6.38 & 6.38 & 6.64 & 6.64 & 7.50 & 7.50 & 7.70 & 7.70 & 8.94 & 8.94 & 9.46 & 9.46 & 12.87 & 12.87 & 7.82 & 7.82 & 5.615 .61 \\
\hline Fatu & .23 & 5.23 & 5.39 & 5.39 & 5.54 & 5.54 & 6.36 & 6.36 & 6.63 & 6.63 & 7.49 & 7.49 & 7.69 & 97.69 & 8.92 & 8.92 & 9.44 & 9.44 & 12.75 & 12.75 & 7.80 & 7.80 & 5.605 .60 \\
\hline $\begin{array}{c}\text { Oelon } \\
\text { Haukolo }\end{array}$ & 36 & 5.36 & 5.52 & 5.52 & 5.67 & 5.67 & 6.51 & 6.51 & 6.77 & 6.77 & 7.64 & 7.64 & 7.83 & 37.83 & 9.10 & 9.10 & 9.64 & 9.64 & 13.19 & 13.19 & 7.98 & 7.98 & 5.745 .74 \\
\hline Labat & 3 & 5.45 & 5.55 & 5.55 & 5.76 & 5.76 & 6.54 & 6.54 & 6.70 & 6.70 & 7.73 & 7.73 & 7.94 & 47.94 & 9.21 & 9.21 & 9.75 & 9.75 & 13.34 & 13.34 & 8.08 & 8.08 & 5.825 .82 \\
\hline Oepura & 5.29 & 5.29 & 5.55 & 5.55 & 5.70 & 5.70 & 6.50 & 6.50 & 6.81 & 6.81 & 7.67 & 7.67 & 7.88 & 87.88 & 9.14 & 9.14 & 9.68 & 9.68 & 13.24 & 13.24 & 8.01 & 8.01 & 5.775 .77 \\
\hline Lasiana & 5.54 & 5.54 & 5.71 & 5.71 & 5.82 & 5.82 & 6.70 & 6.70 & 6.96 & 6.96 & 7.84 & 7.84 & 8.04 & 48.04 & 9.33 & 9.33 & 9.85 & 9.85 & 13.51 & 13.51 & 8.18 & 8.18 & 5.925 .92 \\
\hline Kolhua & 5.32 & 5.32 & 5.48 & 5.48 & 5.63 & 5.63 & 6.46 & 6.46 & 6.72 & 6.72 & 7.59 & 7.59 & 7.79 & 97.79 & 9.0 & 9. & 9.57 & 9.57 & 13.10 & 13.10 & 7. & 7.9 & 5675 \\
\hline
\end{tabular}

\subsection{Curah hujan efektif}

Hujan efektif adalah curah hujan yang dapat ditampung langsung oleh lahan/areal irigasi tanpa melalui saluran irigasi. Besar curah hujan efektif didapat menggunakan data curah hujan 15 tahun Stasiun BMKG Lasiana. Hujan efektif yang diperlihatkan pada Tabel 3.

Tabel 3. Curah hujan efektif sembilan Daerah Irigasi di Kota Kupang

\begin{tabular}{|c|c|c|c|c|}
\hline \multirow{2}{*}{ Bulan } & \multirow{2}{*}{ Periode } & R80 & $\begin{array}{c}\text { Hujan efektif padi } \\
(\mathrm{mm} / \mathrm{bln})\end{array}$ & $\frac{\text { Hujan efektif palawija }}{(\mathrm{mm} / \mathrm{bln})}$ \\
\hline & & $(\mathbf{m m} / \mathbf{b l n})$ & $70 \% \times R_{80}$ & $50 \% \times R_{80}$ \\
\hline \multirow{2}{*}{ Januari } & I & 28.92 & 20.24 & 14.46 \\
\hline & II & 144.90 & 101.43 & 72.45 \\
\hline \multirow[t]{2}{*}{ Februari } & I & 61.80 & 43.26 & 30.90 \\
\hline & II & 49.40 & 34.58 & 24.70 \\
\hline \multirow[t]{2}{*}{ Maret } & I & 102.80 & 71.96 & 51.40 \\
\hline & II & 29.70 & 20.79 & 14.85 \\
\hline \multirow[t]{2}{*}{ April } & I & 0.16 & 0.11 & 0.08 \\
\hline & II & 0.00 & 0.00 & 0.00 \\
\hline \multirow[t]{2}{*}{ Mei } & I & 0.00 & 0.00 & 0.00 \\
\hline & II & 0.00 & 0.00 & 0.00 \\
\hline \multirow[t]{2}{*}{ Juni } & I & 0.00 & 0.00 & 0.00 \\
\hline & II & 0.00 & 0.00 & 0.00 \\
\hline \multirow[t]{2}{*}{ Juli } & I & 0.00 & 0.00 & 0.00 \\
\hline & II & 0.00 & 0.00 & 0.00 \\
\hline \multirow[t]{2}{*}{ Agustus } & I & 0.00 & 0.00 & 0.00 \\
\hline & II & 0.00 & 0.00 & 0.00 \\
\hline \multirow[t]{2}{*}{ September } & I & 0.00 & 0.00 & 0.00 \\
\hline & II & 0.00 & 0.00 & 0.00 \\
\hline \multirow[t]{2}{*}{ Oktober } & I & 0.00 & 0.00 & 0.00 \\
\hline & II & 0.00 & 0.00 & 0.00 \\
\hline \multirow[t]{2}{*}{ November } & I & 0.00 & 0.00 & 0.00 \\
\hline & II & 15.20 & 10.64 & 7.60 \\
\hline \multirow[t]{2}{*}{ Desember } & I & 43.64 & 30.55 & 21.82 \\
\hline & II & 90.72 & 63.50 & 45.36 \\
\hline
\end{tabular}


Data pada Tabel 3 menunjukkan bahwa besar curah hujan efektif untuk tanaman padi pada Bulan Januari hingga Desember berkisar antara 0.00 - $101.43 \mathrm{~mm}$, sedangkan curah hujan efektif untuk tanaman palawija pada bulan Januari hingga Desember berkisar antara $0.00-72.45 \mathrm{~mm}$.

\subsection{Debit andalan}

Dalam menghitung debit andalan, digunakan data curah hujan 15 tahun stasiun BMKG Lasiana. Adapun hasil perhitungan debit andalan untuk tahun normal $\left(\mathrm{Q}_{50}\right)$ dan tahun kering $\left(\mathrm{Q}_{80}\right)$ ditampilkan pada Tabel 4.

\subsection{Kebutuhan air irigasi}

Analisis kebutuhan air irigasi pada umumnya melakukan prediksi kebutuhan air. Kebutuhan air irigasi akan menggunakan pola tanam padi-palawija-palawija dan padi-padi-palawija dengan empat simulasi di waktu tanam yang berbeda. Penentuan pola tanam dan jadwal tanam dilakukan sebelum menghitung kebutuhan air irigasi. Pada studi kali ini pola tanam yang digunakan adalah dua pola tanam yaitu padi-palawija-palawija dan padi-padi-palawija pada sembilan Daerah Irigasi di Kota Kupang. Untuk itu pola tanam yang direncanakan adalah sebagai berikut:

a. Simulasi 1

Pada rencana simulasi 1 digunakan pola tanam dengan jadwal tanam dimulai dengan penyiapan lahan pada bulan Desember I dan panen pada bulan Maret II.

b. Simulasi 2

Pada rencana simulasi 2 digunakan pola tanam dengan jadwal tanam dimulai dengan penyiapan lahan pada bulan November II dan panen pada bulan Maret I.

c. Simulasi 3

Pada rencana simulasi 3 yang digunakan pola tanam dengan jadwal tanam dimulai dengan penyiapan lahan pada bulan November I dan panen pada bulan Februari II.

d. Simulasi 4

Pada rencana simulasi 4 digunakan pola tanam dengan jadwal tanam dimulai dengan penyiapan lahan pada bulan Oktober II dan panen pada bulan Februari I.

Tabel 4. Debit andalan sembilan Daerah Irigasi di Kota Kupang

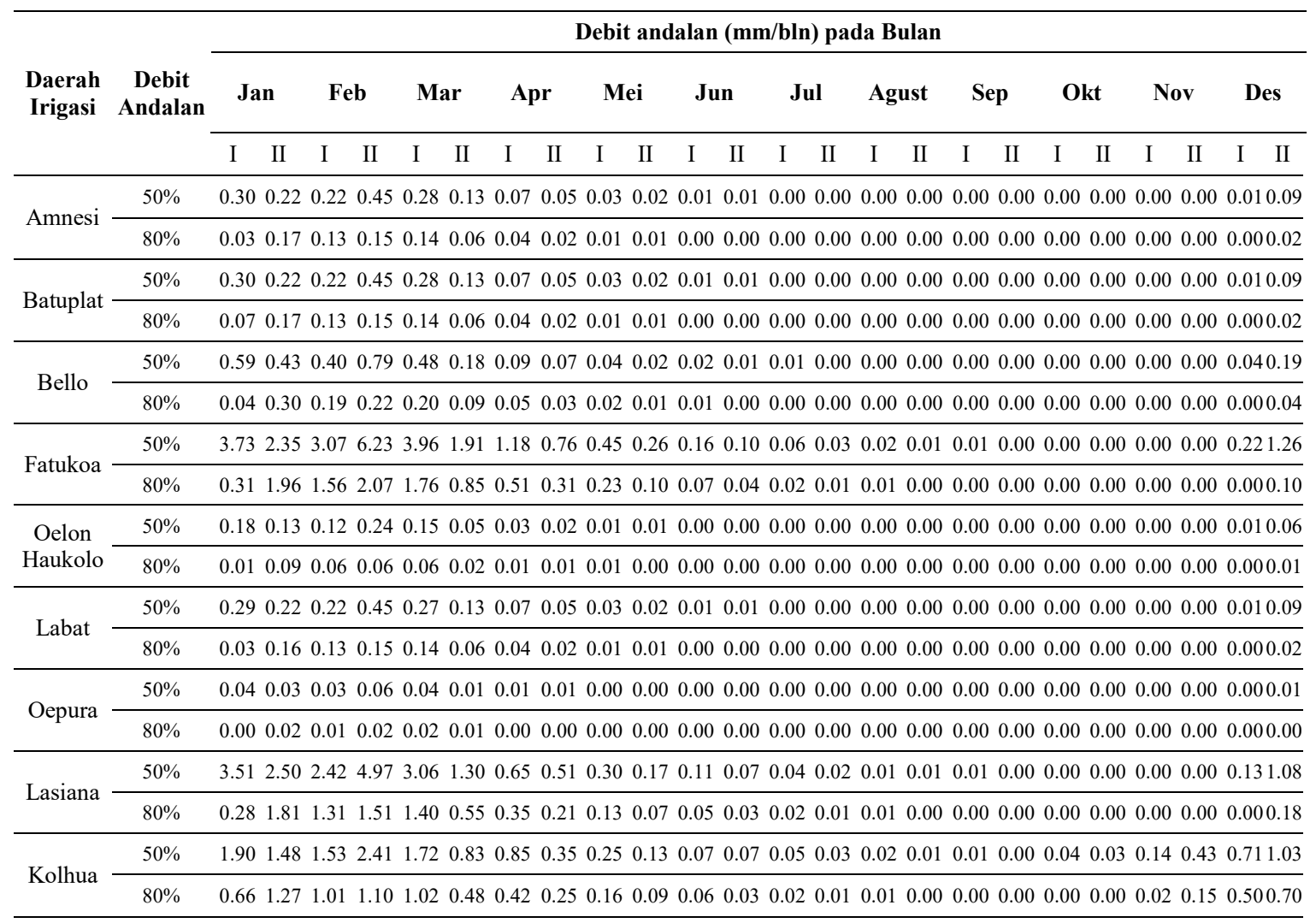


Berdasarkan hasil perhitungan empat simulasi kebutuhan air irigasi untuk pola tanam padipalawija-palawija dan padi-padi-palawija, simulasi dengan kebutuhan air irigasi yang paling kecil adalah simulasi 1 yang masa tanamnya dimulai pada awal musim hujan yakni Bulan Desember, sehingga ketersediaan air yang ada cukup besar dan membuat kebutuhan air irigasi yang diperlukan semakin kecil. Oleh karena itu, berikut akan ditampilkan tabel kebutuhan air irigasi simulasi 1 pada Tabel 5 dan Tabel 6. Untuk besar kebutuhan air irigasi simulasi 1 untuk sembilan daerah irigasi kemudian akan diplot ke dalam grafik yang dapat dilihat pada Gambar 2 dan Gambar 3.

Berdasarkan grafik kebutuhan air irigasi pola tanam padi-palawija-palawija sembilan Daerah Irigasi yang ditunjukkan pada Gambar 2. Daerah irigasi yang memiliki kebutuhan paling besar adalah Daerah Irigasi Fatukoa. Untuk grafik kebutuhan air irigasi pola tanam padi-padi-palawija sembilan Daerah Irigasi yang ditunjukkan pada Gambar 3, memiliki hasil yang sama dengan Gambar 2 yakni Daerah Irigasi Fatukoa sebagai daerah irigasi yang memiliki kebutuhan air irigasi paling besar dari antara sembilan daerah irigasi tersebar di Kota Kupang.

Tabel 5. Kebutuhan air irigasi Simulasi 1 Pola Tanam Padi-Palawija-Palawija pada 9 DI

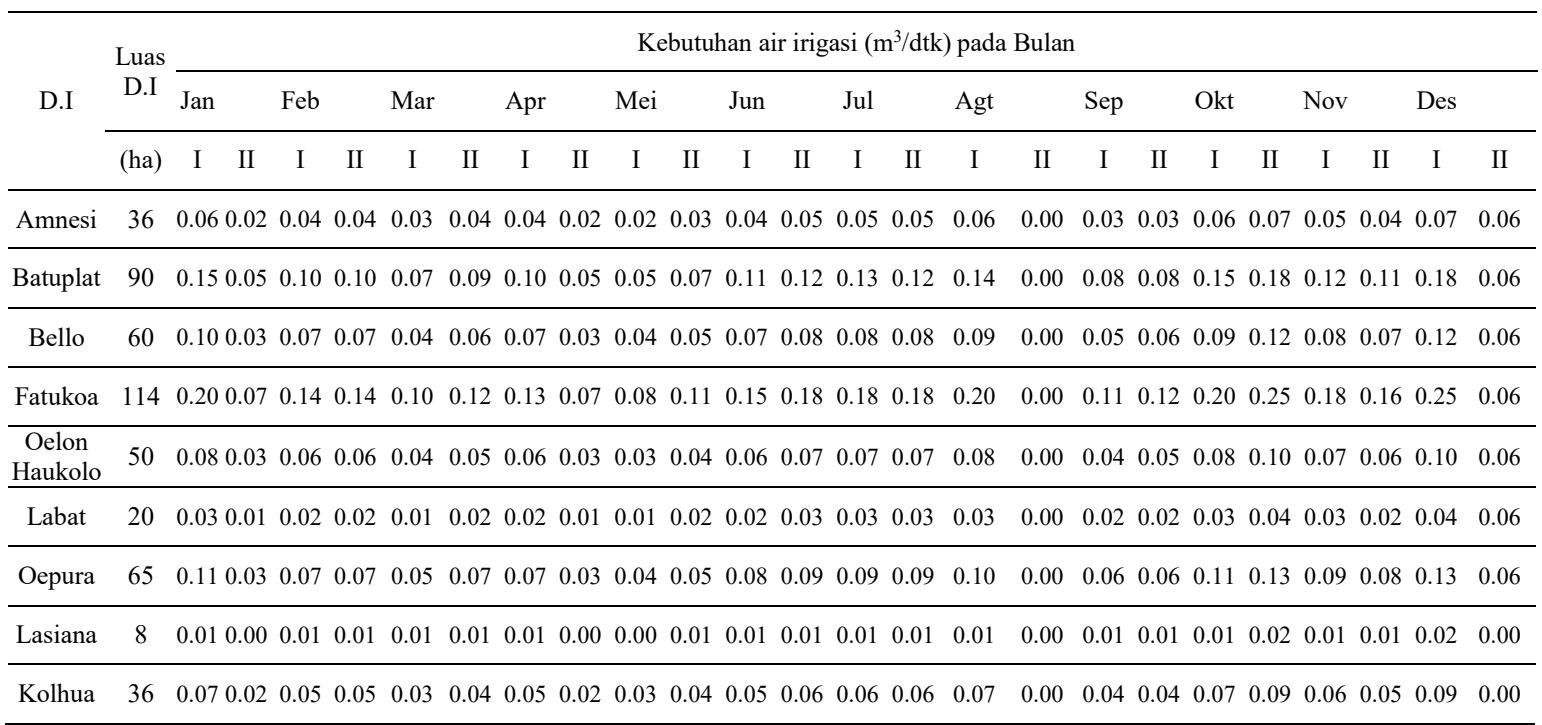

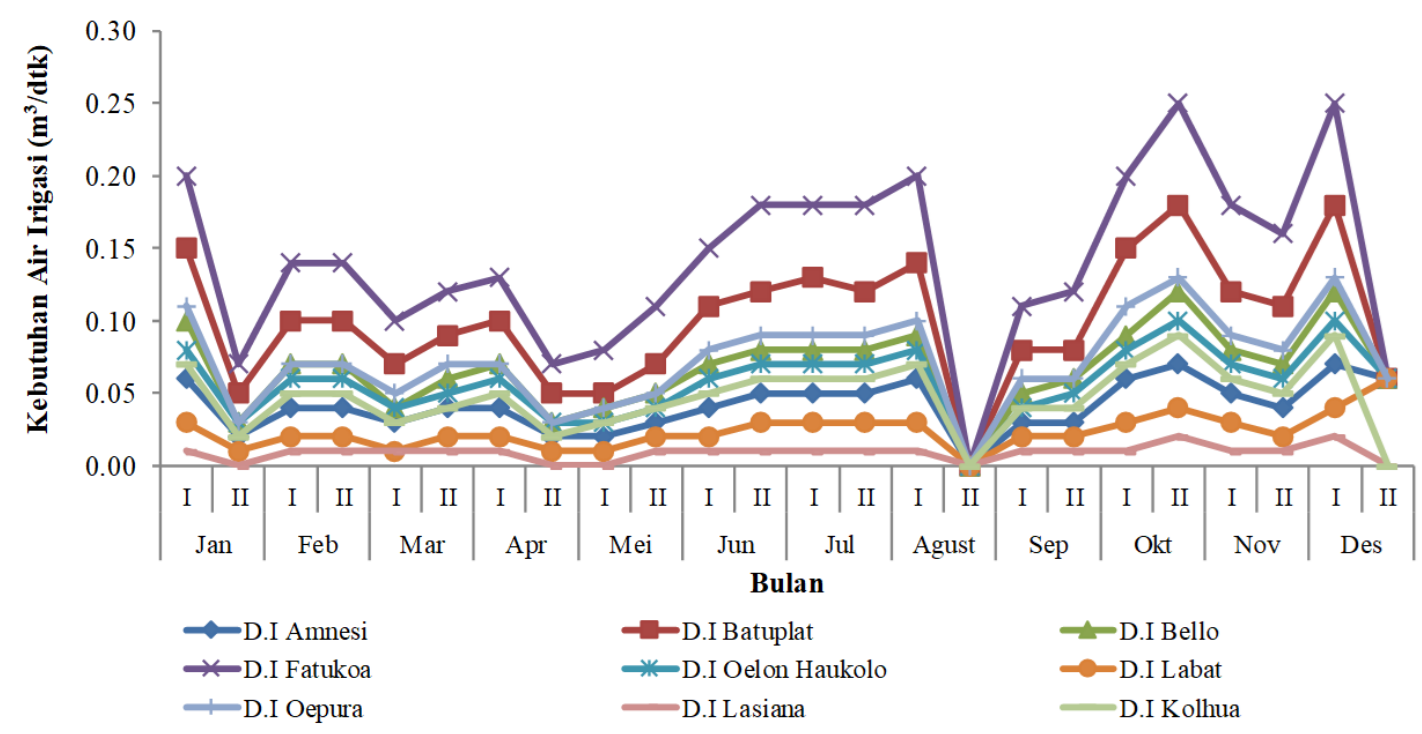

Gambar 2. Kebutuhan air irigasi Simulasi 1 Pola Tanam Padi-Palawija-Palawija sembilan DI 
Tabel 6. Kebutuhan Air Irigasi Simulasi 1 Pola Tanam Padi-Padi-Palawija pada sembilan DI

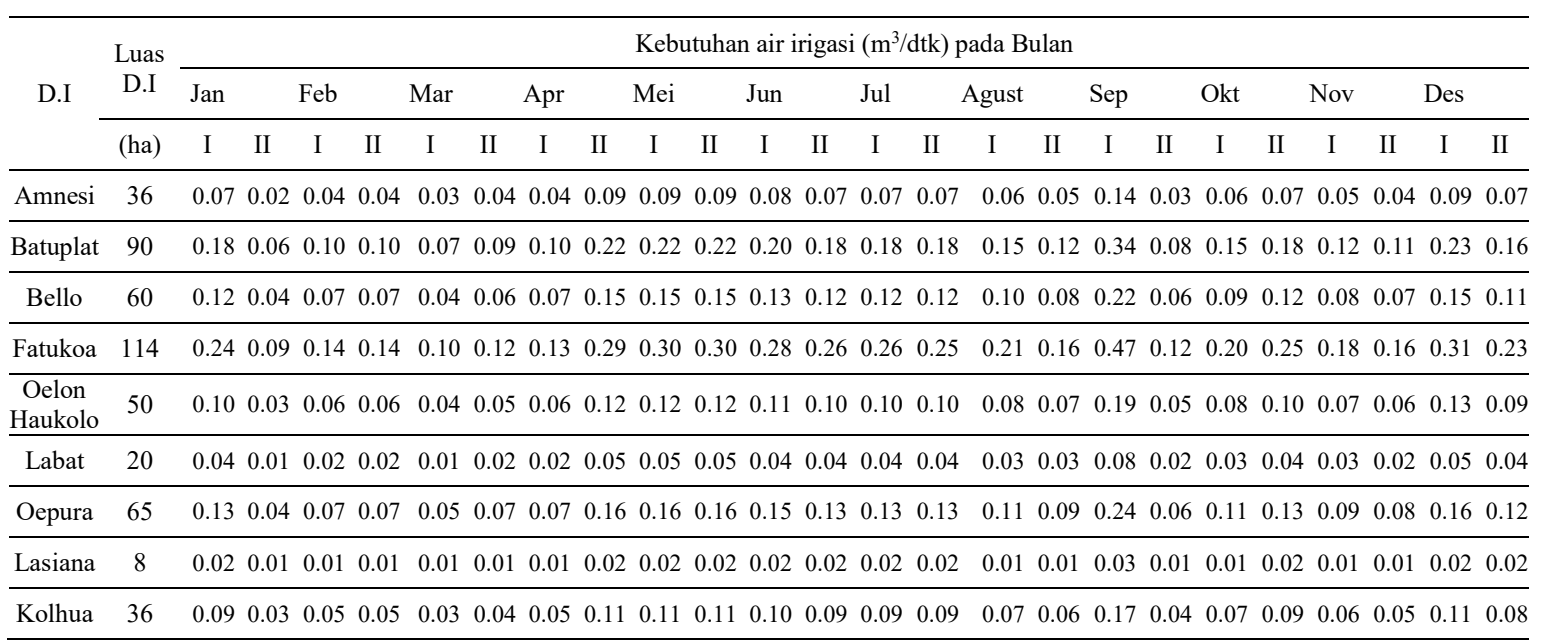

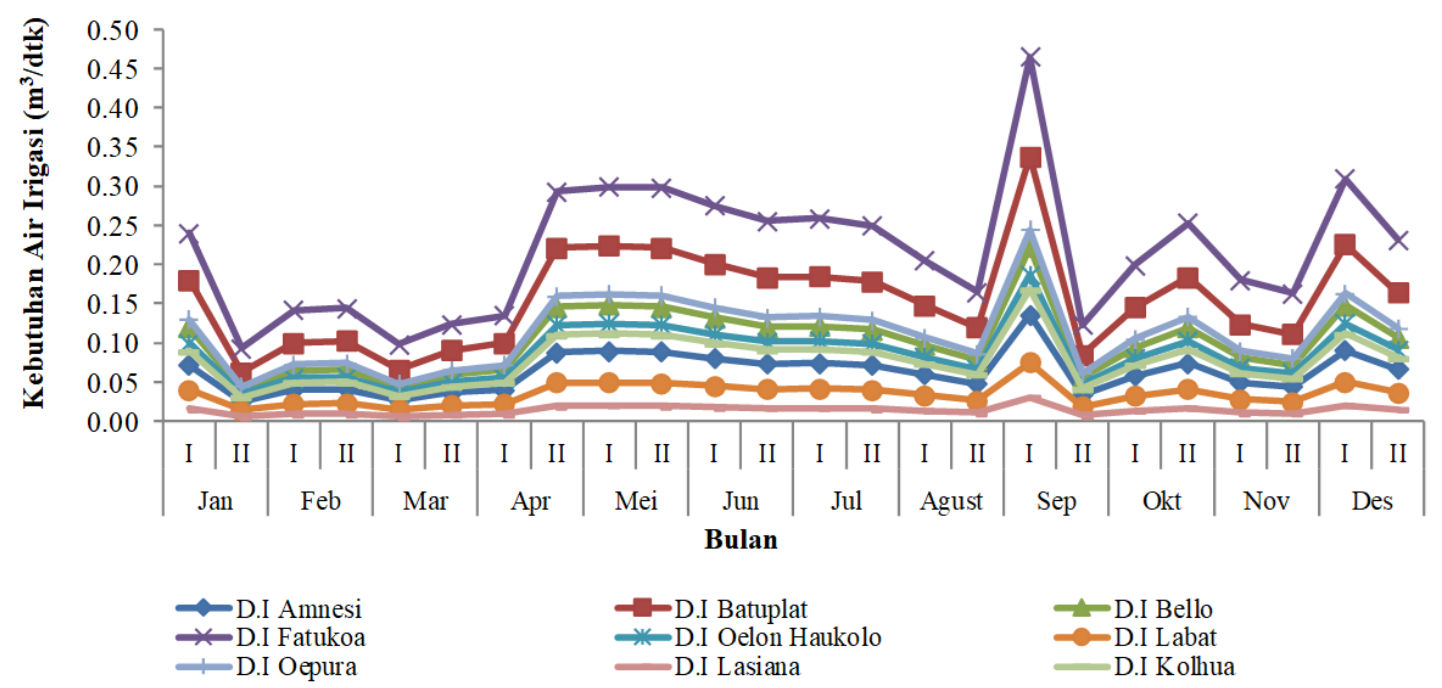

Gambar 3. Kebutuhan air irigasi Simulasi 1 Pola Tanam Padi-Padi-Palawija sembilan DI

Keseimbangan air yang terjadi antara debit andalan dengan kebutuhan air irigasi di Daerah Irigasi Fatukoa sesuai dengan pola tanam yang direncanakan adalah sebagai berikut:

a. Padi-palawija-palawija

Keseimbangan air untuk tahun normal pada bulan Januari - Desember nilai maksimumnya adalah $6.16 \mathrm{~m}^{3} / \mathrm{dtk}$ dan nilai minimumnya adalah $-0.49 \mathrm{~m}^{3} / \mathrm{dtk}$. Sedangkan keseimbangan air untuk tahun kering nilai maksimumnya adalah $3.69 \mathrm{~m}^{3} / \mathrm{dtk}$ dan tahun normal nilai minimumnya adalah -0.44 $\mathrm{m}^{3} / \mathrm{dtk}$.

b. Padi-padi-palawija

Keseimbangan air untuk tahun normal pada bulan Januari - Desember nilai maksimumnya 6.16 adalah $\mathrm{m}^{3} / \mathrm{dtk}$ dan nilai minimumnya adalah $-0.02 \mathrm{~m}^{3} / \mathrm{dtk}$. Sedangkan keseimbangan air untuk tahun kering nilai maksimumnya adalah $3.69 \mathrm{~m}^{3} / \mathrm{dtk}$ dan tahun normal nilai minimumnya adalah -0.49 $\mathrm{m}^{3} / \mathrm{dtk}$.

Luas lahan pertanian yang dapat diairi berdasarkan ketersediaan air yang ada untuk masingmasing pola tanam adalah sebagai berikut:

a. Padi-palawija-palawija

Untuk tahun normal $\left(\mathrm{Q}_{50}\right)$ luas lahan yang dapat diairi adalah 114 ha dan 80 ha untuk tahun kering $\left(\mathrm{Q}_{80}\right)$ 
b. Padi-padi-palawija

Untuk tahun normal $\left(\mathrm{Q}_{50}\right)$ luas lahan yang dapat diairi adalah 114 ha dan 75 ha untuk tahun kering $\left(\mathrm{Q}_{80}\right)$

\section{Kesimpulan}

Pada sembilan daerah irigasi di Kota Kupang diperoleh bahwa musim tanam pertama (MT-I) memberikan hasil optimal dimana pola tanam padi-palawija-palawija (pd-pw-pw) membutuhkan air irigasi rata-rata sebesar $0.111 \mathrm{~m}^{3} / \mathrm{dtk}$. Untuk pola tanam padi-padi-palawija membutuhkan air irigasi rata-rata sebesar $0.138 \mathrm{~m}^{3} / \mathrm{dtk}$. Kebutuhan air yang paling tinggi terjadi pada musim tanam pertama (MT-I) yakni pada bulan Desember I - Maret II dimana merupakan musim hujan dengan debit tersedia yang cukup besar sehingga dapat memenuhi kebutuhan air irigasi yang besar juga. Untuk musim tanam kedua dan ketiga, rata-rata berkisar pada $0.00-0.02 \mathrm{~m}^{3} / \mathrm{dtk}$ dimana pada bulan-bulan tersebut adalah musim kemarau dengan debit air tersedia yang kecil.

Daerah Irigasi yang memiliki kebutuhan air paling tinggi adalah Daerah Irigasi Fatukoa dan yang paling kecil adalah Daerah Irigasi Lasiana. Ini menunjukkan bahwa semakin besar luasan daerah irigasi potensial yang ada mengakibatkan kebutuhan air irigasi yang ada pada musim tanam I - musim tanam IV akan semakin besar juga, dikarenakan luasan Daerah Irigasi Fatukoa sebesar 114 Ha. Untuk pola tanam padi-palawija-palawija dan padi-padi-palawija adalah pola tanam dengan 2 kali musim tanam saja karena kurangnya ketersediaan air, khususnya pada musim tanam ketiga (MT-III) dan musim tanam keempat (MT-IV) yang berada pada puncak musim kemarau sehingga tidak memungkinkan untuk dilakukan kegiatan tanam menanam.

\section{Daftar Pustaka}

Badan Meteorologi Klimatologi dan Geofisika (BMKG). 2019. Pelayanan Jasa Informasi Klimatologi Informasi. Lasiana Kota Kupang. Nusa Tenggara Timur.

Badan Pusat Statistik. 2017. Provinsi Nusa Tenggara Timur Dalam Angka 2017. BPS Provinsi Nusa Tenggara Timur.

Badan Pusat Statistik. 2018. Provinsi Nusa Tenggara Timur Dalam Angka 2018. BPS Provinsi Nusa Tenggara Timur.

Balai Wilayah Sungai Nusa Tenggara II. Satuan Kerja Non Vertikal Tertentu Bidang Pelaksanaan Jaringan Pemanfaatan Air.

Banjarnahor, D. Simanjuntak, B.H. 2015. "Pola Tanam Kabupaten Sumba Tengah Yang Sesuai Dengan Curah Hujan Setempat.” In Konser Karya Ilmiah, , Vol 1, 97-107.

Bunganaen, Wilhelmus et al. 2020. "Analisis Ketersediaan Air Terhadap Pola Tanam Dan.” IX(1): 1526.

Dinas Pekerjaan Umum dan Perumahan Rakyat Kota Kupang. 2018. Laporan Akhir: Penyusunan Database Daerah Irigasi Kota Kupang. Kupang: PT. Siarplan Utama Konsultan.

Hadisusanto, Nugroho. 2010. Aplikasi Hidrologi. Yogyakarta: Jogja Media Utama.

Killa, Yonce Melyanus, Bistok Hasiholan Simanjuntak, and Nugraheni Widyawati. 2019. "Penentuan Pola Tanam Padi Dan Jagung Berbasis Neraca Air Di Kecamatan Lewa Kabupaten Sumba Timur." agriTECH.

Krisnayanti, Denik S., Maria D. A. Lungan, and Dolly W. Karels. 2020. "Simulasi Pola Tata Tanam Daerah Irigasi Raknamo.” IX(1): 165-78.

Sayonara, Ramzy, and Rachmad Djoko Siswoyo. 2019. “Optimasi Debit Dengan Memaksimalkan Luas Lahan Pertanian Guna Mendapatkan Hasil Produksi Pertanian Yang Maksimal Pada Jaringan Irigasi Weliman Di Kabupaten Malaka.” Jurnal Teknik Sipil 4(1): 18.

Standar Perencanaan Irigasi. Kriteria Perencanaan Bagian Saluran Kp-01. 2013. Standar Perencanaan Irigasi Standar Perencanaan Irigasi. Kriteria Perencanaan Bagian Saluran Kp-O1.

Suhardjono. 1994. Kebutuhan Air Tanaman. Malang: Institut Teknologi Nasional. 